\title{
Circuit and Synaptic Plasticity Mechanisms of Drug Relapse
}

\author{
ํㅏan Dong, ${ }^{1}$ Jane R. Taylor, ${ }^{2}$ Marina E. Wolf, ${ }^{3}$ and $\odot$ Yavin Shaham ${ }^{4}$ \\ ${ }^{1}$ Department of Neuroscience, University of Pittsburgh, Pittsburgh, Pennsylvania 15260, ${ }^{2}$ Department of Psychiatry, Yale School of Medicine, Yale \\ University, New Haven, Connecticut 06511, 3 Department of Neuroscience, Chicago Medical School, Rosalind Franklin University of Medicine and Science, \\ Chicago, Illinois 60064, and 4Behavioral Neuroscience Branch, Intramural Research Program, National Institute on Drug Abuse, National Institutes of \\ Health, Bethesda, Maryland 20892
}

High rates of relapse to drug use during abstinence is a defining feature of human drug addiction. This clinical scenario has been studied at the preclinical level using different animal models in which relapse to drug seeking is assessed after cessation of operant drug self-administration in rodents and monkeys. In our Society for Neuroscience (SFN) session entitled "Circuit and Synaptic Plasticity Mechanisms of Drug Relapse," we will discuss new developments of our understanding of circuits and synaptic plasticity mechanisms of drug relapse from studies combining established and novel animal models with state-of-the-art cellular, electrophysiology, anatomical, chemogenetic, and optogenetic methods. We will also discuss the translational implications of these new developments. In the minireview that introduces our SFN session, we summarize results from our laboratories on behavioral, cellular, and circuit mechanisms of drug relapse within the context of our session.

Key words: alcohol; circuit ablation; cocaine; CP-AMPARs; Daun02 inactivation; diphtheria toxin receptors; drug cues; homeostatic plasticity; incubation of drug craving; reinstatement; relapse; silent synapse

\section{Introduction}

A central problem in drug addiction treatment is high rates of relapse to drug use during abstinence (Wikler, 1973; O'Brien, 2005). Despite many years of intense preclinical and clinical research on relapse to drug use (Kalivas and O'Brien, 2008; Sinha et al., 2011), relapse rates remained essentially unchanged during the last 4 decades (Hunt et al., 1971; Sinha, 2011; Fig. 1).

In abstinent human drug users, drug relapse is often triggered by acute exposure to the self-administered drug (Jaffe et al., 1989), drug-associated cues and contexts (O’Brien et al., 1986), stress (Sinha, 2001), or the experience of withdrawal symptoms or exposure to withdrawal-associated cues (Wikler, 1973). Since the early 1970s, this clinical scenario has been modeled in monkeys (Stretch et al., 1971), rats (Davis and Smith, 1976; de Wit and Stewart, 1981), and mice (Highfield et al., 2002), using the extinction-reinstatement model (Stewart and de Wit, 1987). In this model, nonreinforced drug seeking induced by exposure to a drug (priming; de Wit and Stewart, 1981), drug-associated cues and contexts (Meil and See, 1996; Katner and Weiss, 1999; Crombag and Shaham, 2002), stress (Shaham and Stewart, 1995), or

\footnotetext{
Received July 30, 2017; revised Sept. 11, 2017; accepted Sept. 12, 2017.

The writing of the article was supported by the Intramural Research Program of the National Institute on Drug Abuse (to Y.S.); Grants DA-043443, DA-041480, and AA-012870 (to J.R.T.); Grants DA-023206, DA-034856, DA040620, and DA-44538 (to Y.D.); and Grants DA-015835 and DA-009621 (to M.E.W.). J.R.T. thanks Dr. Colby Keister, whose thesis work formed the basis for research described in the last section of the review and in Figure 4. We also thank Marco Venniro for his help in preparing the figures of the review.

The authors declare that they have no competing financial interests.

Correspondence should be addressed to either of the following: Yan Dong, Department of Neuroscience, University of Pittsburgh, Pittsburgh, PA 15260, E-mail: yandong@pitt.edu; or Yavin Shaham, Behavioral Neuroscience Branch, Intramural Research Program, National Institute on Drug Abuse, National Institutes of Health, Bethesda, MD 20892,E-mail: yavin.shaham@nih.gov.

DOI:10.1523/JNEUROSCI.1821-17.2017

Copyright $\odot 2017$ the authors $\quad 0270-6474 / 17 / 3710867-10 \$ 15.00 / 0$
}

withdrawal states (Shaham et al., 1996) is assessed after extinction of the drug-reinforced operant responding (Shaham et al., 2003). During the last 2 decades, many studies have used the reinstatement model to identify cellular, receptor, neurotransmitter, and circuit mechanisms of relapse to drug use and to identify novel pharmacological treatments (Self, 2004; Kalivas et al., 2009; Bossert et al., 2013; Mantsch et al., 2016). Some of these led to prospective clinical trials in human addicts (LaRowe et al., 2013; Kowalczyk et al., 2015; Schwandt et al., 2016).

From a translational perspective, a potential limitation of the reinstatement model is that abstinence in humans is not due to operant extinction and typically is either forced (incarceration or inpatient treatment) or voluntary due to either the negative consequences of chronic drug use or the availability of alternative nondrug rewards in the addict's environment (Marlatt, 1996; Epstein and Preston, 2003). Thus, more recently investigators have incorporated these facets of human abstinence into newer models of drug relapse that do not include an extinction component (Marchant et al., 2013; Venniro et al., 2016).

In the sections below, we summarize the results from our neurobiological studies in which we used three animal models of drug relapse. In the first two sections, Y.D. and M.E.W. will describe results from studies using an animal model of relapse after forced abstinence in which drug seeking progressively increases after the cessation of cocaine self-administration, a phenomenon termed "incubation of cocaine craving" (Grimm et al., 2001). In this model, rats are first trained to self-administer a drug and are then tested for nonreinforced drug seeking at different time periods of home-cage forced abstinence. During the relapse tests, the rats are brought back to the drug self-administration environment (the operant chambers), and lever presses (or nose-pokes) lead to contingent presentations of discrete cues previously paired 

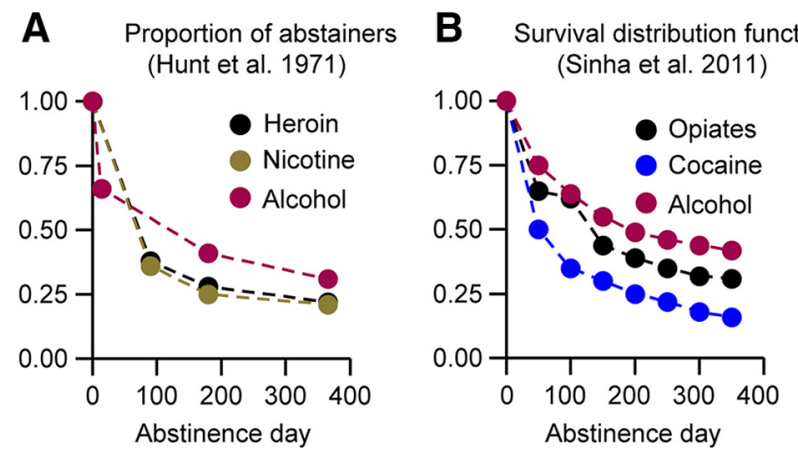

Figure 1. Relapse rates in 1971 and 2011. A, B, Data redrawn from Figure 1 of Hunt et al. (1971) $(\boldsymbol{A})$ and Figure 1 of Sinha et al. (2011) $(\boldsymbol{B})$ on relapse to drug use in addiction clinics.

with drug infusions (Venniro et al., 2016). The preclinical incubation of drug-craving studies inspired clinical studies demonstrating that this phenomenon is observed in human addicts exposed to drug cues during abstinence (Bedi et al., 2011; Wang et al., 2013; Li et al., 2015a; Parvaz et al., 2016).

In the third section, Y.S. will describe the initial behavioral and neurobiological characterization of a new variation of the classical incubation of drug craving model in which the incubation of drug craving is observed after choice-based voluntary abstinence in the drug environment (Caprioli et al., 2015). In the fourth section, J.R.T. will describe studies on the circuit mechanisms of discrete cue-induced reinstatement of drug seeking. In this model, extinction of the drug-reinforced responding occurs in the absence of a discrete cue previously paired with drug infusions during the training phase, and during the subsequent reinstatement tests, lever presses lead to contingent delivery of the cue (Meil and See, 1996). J.R.T. and colleagues used this model to investigate the involvement of limbic corticostriatal circuits in both extinction and reinstatement of alcohol seeking, using a novel viral methodology for ablating neural projections (Keistler et al., 2017).

\section{Withdrawal-dependent plasticity leading to incubation of cocaine craving}

Incubation of cue-induced cocaine craving serves as a clinically relevant rodent model to study mechanisms underlying persistent vulnerability to relapse in abstinent drug users ( $\mathrm{Lu}$ et al., 2004; Parvaz et al., 2016; Wolf, 2016). While the expression of "incubated" cocaine craving involves many brain regions and several transmitter systems (Pickens et al., 2011), a critical mechanism is synaptic accumulation of $\mathrm{Ca}^{2+}$-permeable AMPA receptors (CP-AMPARs) in excitatory synapses on nucleus accumbens (NAc) medium spiny neurons (MSNs; Wolf, 2016). In drug-naive rats or rats tested during the first several weeks after withdrawal from extended-access cocaine self-administration, GluA2-containing $\mathrm{Ca}^{2+}$-impermeable AMPARs (CI-AMPARs) are responsible for the majority of excitatory synaptic transmission, although $\sim 5 \%$ of the evoked EPSC is mediated by CPAMPARs. However, after prolonged withdrawal ( $>30 \mathrm{~d})$, when incubation of cocaine craving becomes pronounced, the contribution of CP-AMPARs (homomeric GluA1 receptors) to synaptic transmission increases and then remains high for at least 2 more months (Conrad et al., 2008; Wolf and Tseng, 2012). Once this has occurred, the responsiveness of NAc core MSNs to glutamate drive is strengthened (Purgianto et al., 2013), presumably due to the higher conductance of CP-AMPARs compared with CI-AMPARs. Consistent with these findings, the incubation of cocaine craving is associated with an increase in the firing of NAc core neurons that encode cocaine-related information (Hollander and Carelli, 2005, 2007; Guillem et al., 2014).

Levels of CP-AMPARs are also elevated in the NAc shell (NAcSh) after incubation of cocaine craving (McCutcheon et al., 2011a; Lee et al., 2013; Ma et al., 2014) and CP-AMPARs in both core and shell play a necessary role in the expression of the incubation of craving. Thus, acute pharmacological inhibition of NAc core CP-AMPARs or their removal via activation of metabotropic glutamate receptor 1 (mGluR1) reduces the expression of incubated cocaine craving (Conrad et al., 2008; Loweth et al., 2014). Similarly, optogenetic internalization of CP-AMPARs within selected excitatory NAc afferents decreases incubated cocaine seeking after $45 \mathrm{~d}$ of withdrawal (Lee et al., 2013; Ma et al., 2014). Together, the results summarized above suggest that synaptic incorporation of CP-AMPARs after prolonged withdrawal enhances MSN activation in response to glutamate released by cocaine-paired cues and thereby intensifies the drug-seeking response.

What mechanisms trigger and then maintain elevated CPAMPAR levels? We are pursuing several related aspects of this question, focusing on the NAc core. Based on evidence that NAc CP-AMPAR levels are normalized in brain slices from "incubated rats" by acute $(1 \mathrm{~h})$ disruption of protein translation (Scheyer et al., 2014), we are investigating mechanisms regulating protein translation in NAc MSNs under control conditions and dysregulation of these mechanisms during the incubation of craving. As part of this, we are testing the hypothesis that disinhibition of GluA1 translation accounts for increased levels of homomeric GluA1 receptors in incubated rats. However, even if we can account for the formation of CP-AMPARs within NAc neurons during the incubation of craving, a distinct question is why they accumulate in synapses.

An early step in synaptic remodeling associated with incubation of cocaine craving is an increase in the number of GluN2Bcontaining silent synapses in the NAc that is detectable by withdrawal day 1 ; these silent synapses are ultimately "filled," at least in some projections, with CP-AMPARs (Lee et al., 2013; Ma et al., 2014). In the NAc core, where CP-AMPAR levels increase only after $\sim 30$ withdrawal days (Wolf and Tseng, 2012), this leaves a significant temporal gap between silent synapse formation in NAc and CP-AMPAR insertion. This suggests that intermediate plasticity steps are required. By studying NMDAR transmission in NAc core over the first 2 months of withdrawal, we have found that an initial increase in GluN2B-containing receptors during the first week of withdrawal is followed, $\sim 1-2$ weeks later, by the appearance of NMDARs that contain the GluN3 subunit along with GluN2B (Christian et al., 2017). Similar NMDARs have been implicated in cocaine action in the ventral tegmental area (Yuan et al., 2013; Creed et al., 2016). The presence of GluN3 subunits endows NMDARs with atypical properties, namely low sensitivity to $\mathrm{Mg}^{2+}$ block, low $\mathrm{Ca}^{2+}$ permeability, and lower conductance (Cull-Candy and Leszkiewicz, 2004; Henson et al., 2010; Pachernegg et al., 2012; Paoletti et al., 2013). It is possible that GluN3-containing NMDARs emerge as part of a homeostatic response to decreased membrane excitability or decreased activity of excitatory afferents after withdrawal from cocaine, since their presence will increase transmission at hyperpolarized potentials due to absence of $\mathrm{Mg}^{2+}$ block. However, their inability to pass $\mathrm{Ca}^{2+}$ may have different functional consequences. Of greatest interest is the tonic suppression of local protein translation mediated by NMDARs (Sutton et al., 2006; Autry et al., 2011; Kavalali and Monteggia, 2015), which has been 
shown to depend upon $\mathrm{Ca}^{2+}$ entry through the NMDAR channel (Scheetz et al., 2000; Reese and Kavalali, 2015). We speculate that synaptic incorporation of GluN3-containing NMDARs disinhibits protein translation during the incubation of cocaine craving and thereby accounts for at least a component of the dysregulated translation shown to be required for CP-AMPAR maintenance in NAc synapses.

Another important and better characterized adaptation that emerges in an intermediate withdrawal time period (detectable after 25 but not 14 withdrawal days) involves mGluR1. The ability of pharmacological activation of mGluR1 to remove CPAMPARs from NAc synapses (McCutcheon et al., 2011b; Loweth et al., 2014) and other synapses (Loweth et al., 2013) suggests that endogenous glutamate tone at mGluR1 may help to maintain low CP-AMPAR levels in the NAc core under normal conditions and conversely that decreased mGluR1 function after withdrawal could account for CP-AMPAR accumulation. Indeed, we demonstrated that a loss of mGluR1 tone, attributable to reduced mGluR1 surface expression, precedes and enables CP-AMPAR accumulation during the incubation of craving (Loweth et al., 2014). During late withdrawal, the consequences of slowing CP-AMPAR removal in this manner may be exacerbated by accelerated CP-AMPAR insertion due to enhanced PKA phosphorylation of GluA1 (Ferrario et al., 2011). It is important to note that, despite the reduction in surface mGluR1, sufficient receptor remains to be activated by exogenous agonists, explaining the ability of mGluR1-positive allosteric modulators (PAMs) to remove CP-AMPARs and reduce incubation of cocaine craving. These results establish mGluR1 PAMs as potential therapeutic agents for reducing cocaine craving and prolonging abstinence (Loweth et al., 2014).

Studies are in progress to investigate the relationships among homeostatic plasticity, NMDAR transmission, protein translation, and CP-AMPAR accumulation.

\section{Homeostatic dysregulation in cocaine relapse}

Repeated exposure to addictive drugs induces many cellular and circuit alterations in the brain (Nestler, 2001), some of which contribute to drug self-administration and relapse, as assessed in rodent models (Shaham and Hope, 2005; Thomas et al., 2008; Jonkman and Kenny, 2013; Dong and Nestler, 2014). Among drug-associated alterations, some are induced with a clear signature of Hebbian plasticity (i.e., they are induced by drug experience to promote drug-associated memories and behaviors; White, 1996; Hyman et al., 2006), while other alterations are likely drug-induced homeostatic responses (i.e., they are induced to compensate for the impact of the drug on neurons and neural networks; Aghajanian, 1978; Nestler and Aghajanian, 1997; Kalivas, 2005; Huang et al., 2011). Homeostatic responses play a key role in maintaining stable neuronal output under most physiological circumstances (Turrigiano and Nelson, 2004; Davis, 2013; Yee et al., 2017). However, homeostatic responses can also go awry due to insufficient or excessive compensation, or the involvement of other factors (Turrigiano and Nelson, 2004; Davis, 2013; Yee et al., 2017). In this case, they become homeostatic dysregulations that may cause adverse consequences to the drug addict (Huang et al., 2011). It has long been hypothesized that after drug exposure, homeostatic regulations and dysregulations are extensively triggered and continuously evolve, a process that may contribute to the progression of drug addiction (Solomon and Corbit, 1974; Koob and Le Moal, 1997). It remains poorly understood under what conditions homeostatic alterations are formed at the cellular level after drug exposure and how they

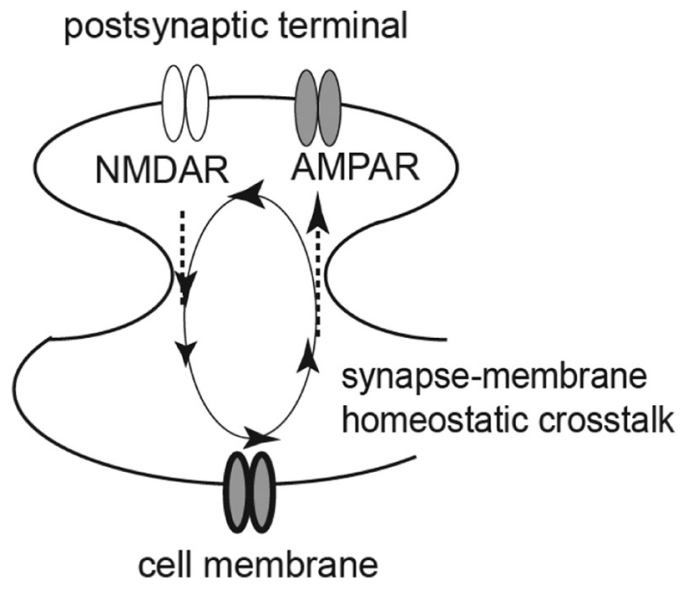

Figure 2. A diagram showing a homeostatic cross talk between excitatory synaptic inputs and membrane properties in NAc MSNs. Specifically, in NAc MSNs, an increase or decrease in the excitatory synaptic strength induces a homeostatic decrease or increase in the intrinsic membrane excitability, and vice versa.

evolve to promote drug self-administration and relapse (Huang et al., 2011).

Targeting this knowledge gap, we focus on cocaine-induced homeostatic dysregulation in NAcSh MSNs using a drug-relapse model: the incubation of cocaine craving (Grimm et al., 2001). The functional output of MSNs is determined by the integration of excitatory synaptic input and membrane excitability (Ishikawa et al., 2009; Huang et al., 2011; Wolf, 2016). Lacking intrinsic pace-making mechanisms, excitatory synaptic inputs provide the primary driving force to depolarize the MSNs, while upon depolarization, the membrane excitability of the MSNs determines whether to fire action potentials and how many action potentials to fire (O'Donnell et al., 1999). Our published (Ishikawa et al., 2009) and unpublished results reveal a bidirectional homeostatic plasticity between the excitatory synaptic input and membrane excitability of NAcSh MSNs, which we termed "synapse-membrane homeostatic cross talk" (SMHC). Through this SMHC, an increase or decrease in the excitatory synaptic strength induces a homeostatic decrease or increase in the membrane excitability, and vice versa (Fig. 2). As such, the overall functional output of NAcSh MSNs can be maintained at relatively stable levels.

The excitatory synaptic strength of NAc MSNs is primarily mediated by AMPARs. Our unpublished results show that synaptic GluN2B-containing NMDARs are the synaptic sensors of SMHC; they detect alterations in AMPAR-mediated excitatory synaptic strength, and, through coupling to calcium-calmodulin protein kinase II, these receptors regulate the membrane properties of NAc MSNs. During cocaine self-administration and after short-term withdrawal from cocaine, although the AMPARmediated excitatory synaptic strength in NAc MSNs remains largely unchanged, synaptic GluN2B NMDAR-mediated transmission is upregulated. This constitutes a false signal of increased excitatory synaptic strength and triggers the first round of synapseto-membrane SMHC to decrease the membrane excitability of NAcSh MSNs, partially through the expression of SK2-type calcium-activated potassium channels. Subsequently, the decreased membrane excitability initiates the second round of membrane-to-synapse SMHC, resulting in synaptic accumulation of CP-AMPARs and the strengthening of NAc excitatory synapses after prolonged withdrawal from cocaine. Thus, a cascade of SMHC-mediated homeostatic dysregulation occurs after 
withdrawal from cocaine to sequentially change two critical neuronal substrates of NAcSh MSNs, the membrane excitability and excitatory synaptic strength.

To determine the behavioral consequence of homeostatic dysregulation cascades after cocaine self-administration, we experimentally prevented cocaine-induced upregulation of GluN2B or SK2 in NAcSh MSNs. Rats with either of these manipulations did not develop incubation of cocaine craving, suggesting that the SMHC-mediated dysregulation cascades gradually change the functional output of NAcSh MSNs, contributing to the development of the incubation of cocaine craving (J. Wang and Y. Dong, unpublished data).

How do SMHC-mediated dysregulation cascades change the functional output of NAcSh MSNs? In a hypothetical model, if an MSN is regarded as a linear electrical unit with an input, a gain, and an output, cocaine-induced SMHC cascades may progressively increase the input and reduce the gain simultaneously, which keeps the input-output balanced at the check point. However, low-intensity excitatory synaptic inputs, which otherwise would trigger action potential firing in drug-naive animals, fail to do so due to reduced membrane excitability, while high-intensity inputs can pass the barrier of reduced membrane excitability and possibly predominate in triggering action potential firing. As such, normal, low-intensity inputs to NAcSh MSNs are suppressed after withdrawal from cocaine, while high-intensity inputs, some of which may be activated by cocaine-associated cues, are prioritized for functional output.

Together, our studies suggest that cocaine self-administration initiates homeostatic dysregulation cascades to progressively alter the functional output of NAc MSNs, promoting relapse to cocaine seeking after prolonged withdrawal from the drug.

\section{Incubation of drug craving after voluntary abstinence: behavioral and neuronal mechanisms}

As mentioned in the previous sections, since the publication of the study by Grimm et al. (2001), we and other investigators have studied cellular and circuit mechanisms of the incubation of drug craving (Pickens et al., 2011; Wolf, 2016). However, despite the translational utility of the established rat incubation of drug craving model (Li et al., 2016), from the human relapse perspective, the limitation of the model is that the abstinence period is experimenter imposed or forced (Venniro et al., 2016). In humans, abstinence is often voluntary due to either adverse consequences of drug use or the presence of alternative rewards (Marlatt, 1996; Epstein and Preston, 2003). Based on these considerations, we recently developed a choice-based rat model of relapse after voluntary abstinence (Caprioli et al., 2015). The model is based on the seminal food versus drug choice studies of Ahmed and colleagues (Lenoir and Ahmed, 2007; Ahmed, 2010).

In our first study, we used two established self-administration models of addiction-escalation of drug self-administration (Ahmed and Koob, 1998) and a DSM-IV-based addiction model in which rats are trained to self-administer a drug for many weeks (Deroche-Gamonet et al., 2004) — to demonstrate that foodsated rats will voluntarily abstain from methamphetamine selfadministration when given a mutually exclusive choice between the drug and palatable food, and that incubation of methamphetamine craving reliably occurs after the alternative nondrug reward is discontinued (Caprioli et al., 2015; Fig. $3 A, B$ ). We also showed that incubation of methamphetamine craving after forced or voluntary abstinence is decreased by systemic injections of AZD8529, a selective positive allosteric modulator of mGluR2. These data extend the findings of previous studies on the important role of glutamate transmission in incubation of drug craving (see previous sections; Lu et al., 2005, 2007). In a subsequent study, we showed that the incubation of methamphetamine craving after voluntary abstinence generalizes to female rats and that, unexpectedly, food-choice voluntary abstinence prevents the emergence of the incubation of heroin craving in both sexes (Venniro et al., 2017a).

In our first circuit mechanism study on the incubation of methamphetamine craving after voluntary abstinence, we used the activity marker Fos (Morgan and Curran, 1991), RNAscope in situ hybridization (Wang et al., 2012), classical dopamine receptor pharmacology, and the Daun02 chemogenetic inactivation procedure (Cruz et al., 2013) to determine the role of dorsolateral striatum (DLS) and dorsomedial striatum (DMS) in this new form of incubation (Caprioli et al., 2017). We chose this brain region because we recently found that the incubation of methamphetamine craving after forced abstinence is associated with increased Fos in both DLS and DMS and that the blockade of D1 family receptors, which inhibit striatal Fos induction (Valjent et al., 2000), in these subregions decrease incubated drug seeking after prolonged forced abstinence (Li et al., 2015b).

The Daun02 inactivation procedure was developed to determine causal roles of neuronal ensembles in learned behaviors (Koya et al., 2009). This method has been used to identify the role of neuronal ensembles in different brain regions in contextinduced relapse to drug seeking (Bossert et al., 2011; Cruz et al., 2014; Rubio et al., 2015), incubation of drug craving after forced abstinence (Fanous et al., 2012; Funk et al., 2016), and reconsolidation of drug reward memories (Xue et al., 2017). In this procedure, selective inhibition of behaviorally relevant activated neuronal ensembles is performed by injecting the prodrug Daun02 into specific brain areas of Fos-lacZ transgenic rats (Kasof et al., 1995) that express $\beta$-galactosidase ( $\beta$-gal; the lac $Z$ gene protein product) in neurons strongly activated during behavior (Koya et al., 2009). Daun02 is cleaved into daunorubicin by $\beta$-gal expressed in strongly activated neurons. Daunorubicin in turn selectively inhibits the strongly activated neurons (but not the surrounding nearby neurons) via either cell death (Pfarr et al., 2015) or the inhibition of calcium-dependent action potentials (Engeln et al., 2016).

We found that methamphetamine seeking was higher after $21 \mathrm{~d}$ of voluntary abstinence than after $1 \mathrm{~d}$ (incubation of methamphetamine craving). We also found that the incubated response was associated with increased Fos expression in DMS but not DLS and that Fos was colabeled with both Drd1 and Drd2. Additionally, DMS injections of SCH39166 or raclopride selectively decreased methamphetamine seeking after 21 abstinence days. Finally, in Fos-lacZ transgenic rats, selective inactivation of relapse test-activated Fos neurons in DMS on abstinence day 18 using the Daun02 procedure decreased incubated methamphetamine seeking on day 21 (Caprioli et al., 2017; Fig. 3C). Together, the results of our initial circuit mechanism study demonstrate a role of DMS dopamine $\mathrm{D}_{1}$ and $\mathrm{D}_{2}$ receptors in the incubation of methamphetamine craving after voluntary abstinence and that DMS neuronal ensembles play a critical role in this incubation.

In conclusion, we have developed a new rat model that allows us and other investigators to study brain mechanisms of relapse and incubation of drug craving after prolonged choice-based voluntary abstinence. We have recently used the model to study the role of central amygdala and glutamatergic projections to this region in relapse after voluntary abstinence (Venniro et al., 2017b). We also currently are developing an extension of our voluntary abstinence-relapse model by using a social peer as the nondrug alternative operant reward instead of palatable food to achieve 


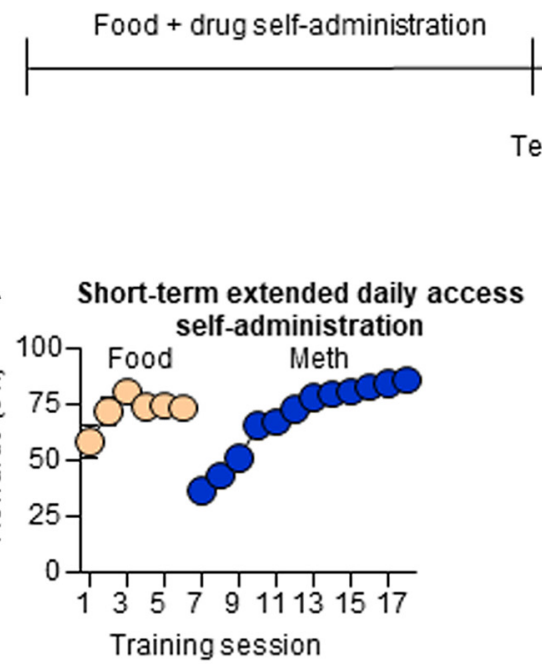

\section{B Long-term limited daily access self-administration}

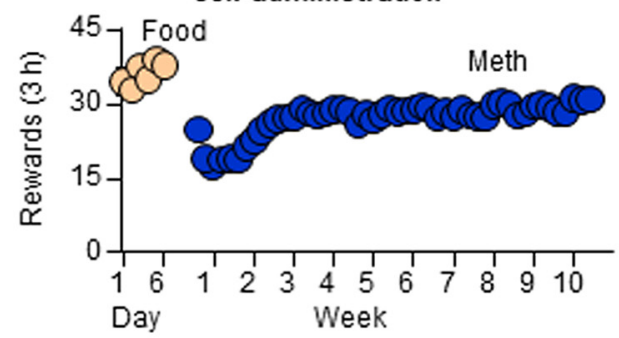

Training session

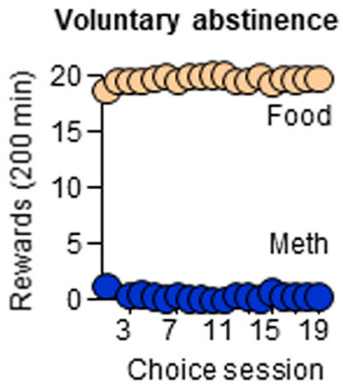

Voluntary abstinence

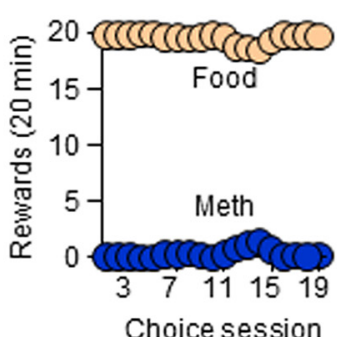

Voluntary or forced abstinence (19 days)
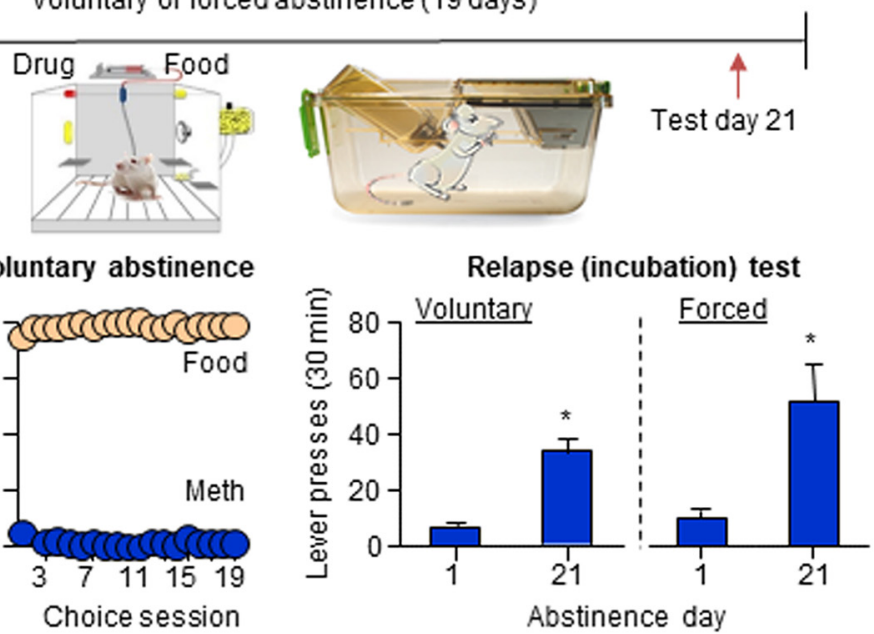

Relapse (incubation) test

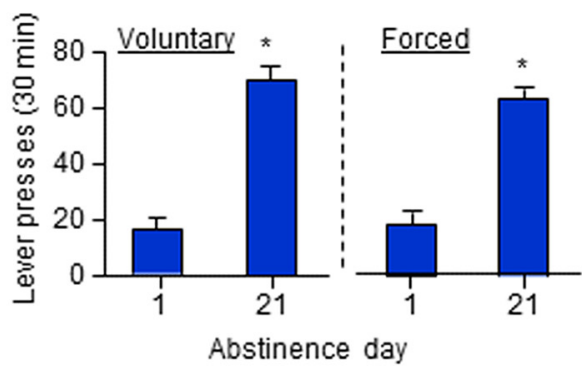

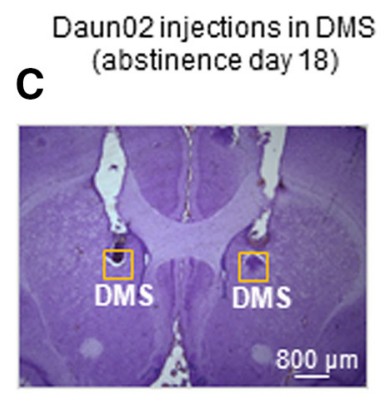
Relapse (incubation) test
(abstinence day 21)

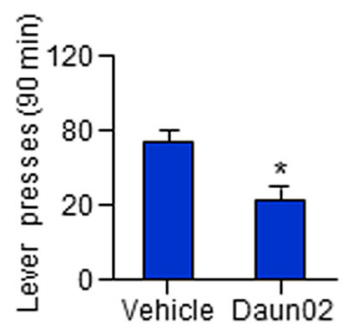

$\beta$-gal counts in DMS

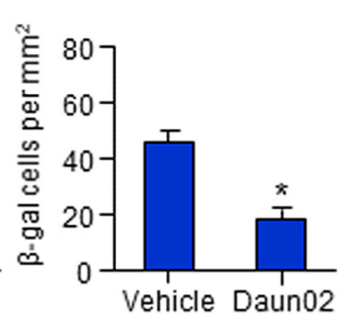

Fos and $\beta$-gal double-labeling in DMS

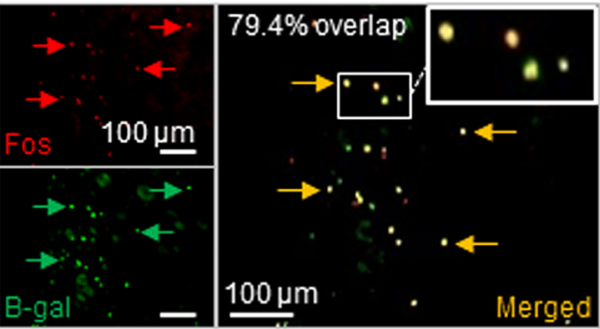

Figure 3. Incubation of methamphetamine craving after choice-based voluntary abstinence: behavioral characterization and role of DMS neuronal ensembles. $A, B$, Voluntary abstinence and incubation of methamphetamine craving after forced or voluntary abstinence in food-sated in rats with a history of food self-administration (five $45 \mathrm{mg}$ palatable food pellets per lever press) and either short-term extended daily access or long-term limited daily access to methamphetamine $(0.1 \mathrm{mg} / \mathrm{kg} / \mathrm{infusion})$ self-administration. During voluntary abstinence, the rats were given 20 discrete trials every $10 \mathrm{~min}$, during which they could earn either the food reward or the drug reward, but not both. During the drug relapse tests, only the drug lever was available, and lever presses on the previously methamphetamine-paired lever led to the delivery of a cue previously paired with drug infusions (extinction conditions). C, Role of DMS neuronal ensembles in the incubation of methamphetamine craving after voluntary abstinence. On abstinence day 18 , the rats were exposed to the methamphetamine self-administration context and cues associated with methamphetamine injections in a 15 min extinction session to induce Fos in DMS. Next, 75 min after the induction session, a time of strong Fos and $\beta$-gal expression, the rats were injected with Daun02 (to inactivate the Fos-positive activated neurons) or vehicle. Three days later, the rats were tested for relapse to methamphetamine seeking as described above, and 90 min later the brains were taken for immunohistochemistry analysis of Fos and $\beta$-gal. Daun02 injections on abstinence day 18 decreased incubated methamphetamine seeking on abstinence day 21 and decreased relapseassociated neuronal activity in DMS, as assessed by $\beta$-gal. The data in $\boldsymbol{A}$ and $\boldsymbol{B}$ are from Caprioli et al. (2015), and the data in $\boldsymbol{C}$ are from Caprioli et al. (2017).

long-term abstinence before the relapse tests (M. Venniro and Y. Shaham, unpublished data). Data from these recently published and unpublished studies will be presented in our Society for Neuroscience symposium.

Role of corticostriatal, corticoamygdalar, and amygdalostriatal projections in drug relapse Relapse to alcohol seeking can be driven by environmental or sensory cues that were previously associated with alcohol intake (Weiss,
2005; Heinz et al., 2009). In both recovering alcoholics and rodent models, cue-induced relapse can occur even after the instrumental response has been extinguished (Ciccocioppo et al., 2001; Field and Duka, 2002; Sinha and Li, 2007). Improved understanding of the circuit mechanisms mediating both extinction and cue-induced relapse to alcohol seeking is critical for the development of effective behavioral and pharmacological treatments for alcoholism.

Studies have shown that cue-induced alcohol seeking depends on the activity of limbic-striatal structures, including basolateral 
A
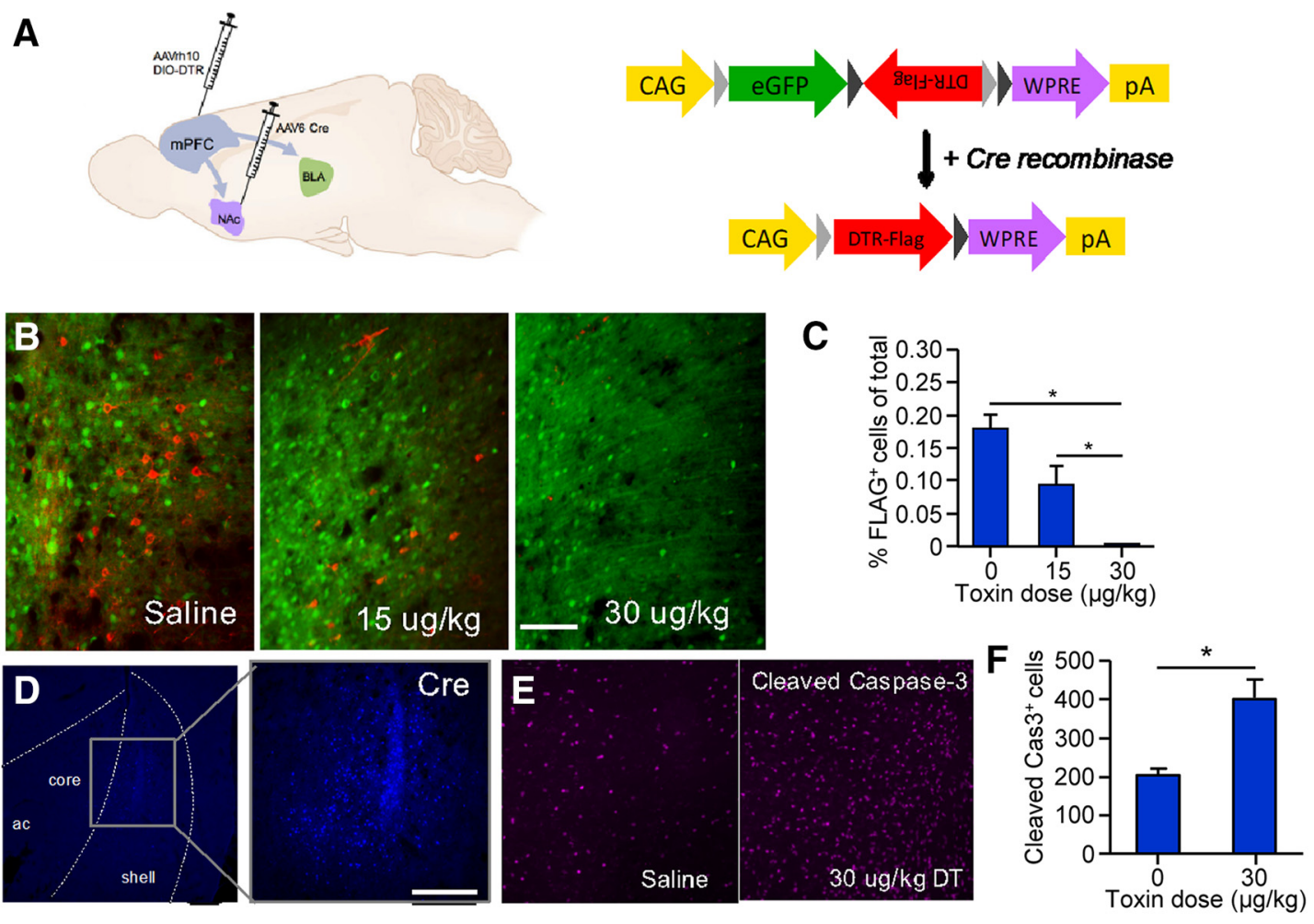

G

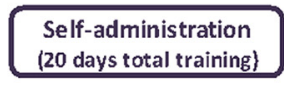

Day 19:

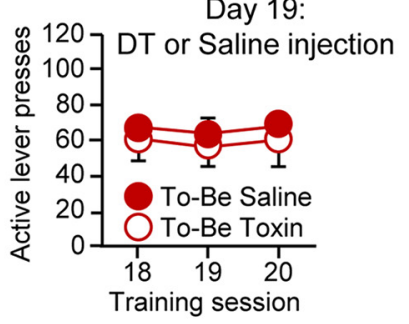

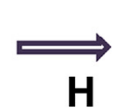

$\mathbf{H}$
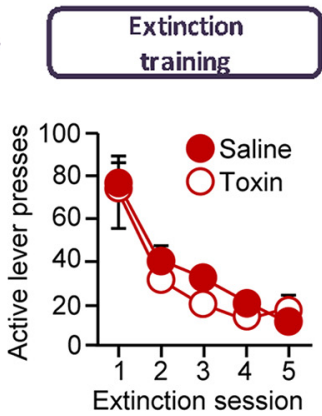

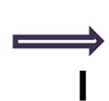

Cue-induced reinstatement test

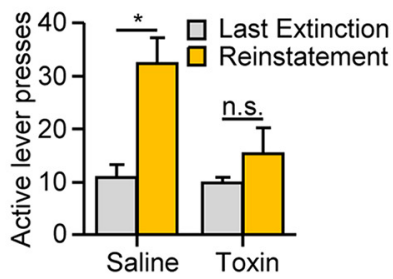

$\mathbf{J}$

Figure 4. Circuit ablation techniques and circuitry of extinction and reinstatement of alcohol seeking. $A-F$, Strategy for target-specific ablation of mPFC afferents. $A$, AAVrh10-DI0-DTR-FLAG was injected into the mPFC, and AAV6-Cre was injected into either the NAc (to target the mPFC $\rightarrow$ NAc pathway) or other pathways such as the mPFC $\rightarrow$ BLA pathway. B, Representative micrographs taken after targeting the $\mathrm{PPFC} \rightarrow$ NAc pathway. Scale bar, $100 \mu \mathrm{m}$. C, Immunohistochemical staining with a FLAG-directed antibody (red) shows a reduction in the percentage of total fluorescent cells that are FLAG-positive after diphtheria toxin injection $\left({ }^{*} p<0.05\right)$. D, Cre-directed antibody shows local expression of AAV-Cre in NAc shell and medial core. Scale bars, $300 \mu \mathrm{m} . \boldsymbol{E}, \boldsymbol{F}$, Cleaved caspase-3 staining $48 \mathrm{~h}$ after injection revealed an increased expression of this apoptosis marker in DT-vs saline-treated rats $\left({ }^{*} p<0.05\right)$. G-I, Rats were injected with viruses to target the $\mathrm{mPFC} \rightarrow$ NAC pathway as described in $\boldsymbol{A}$ and then were trained to self-administer oral alcohol (10\%). $\boldsymbol{G}$, The final $3 \mathrm{~d}$ of self-administration show equal levels of responding for both groups. $\boldsymbol{H}, \boldsymbol{I}$, Circuit ablation did not affect extinction training $(\boldsymbol{H})$, but blocked cue-induced reinstatement $\left(\boldsymbol{I} ;{ }^{*} p<0.05\right)$. (Data are from Keistler et al., 2017). $\boldsymbol{J}$, Hypothesized role of a circuitry-mediating extinction and reinstatement of alcohol seeking. Our data suggest that the $\mathrm{mPFC} \rightarrow \mathrm{NAc}$ projections, but not the $\mathrm{mPFC} \rightarrow$ BLA projections, are necessary for cue-induced reinstatement of alcohol seeking. Additionally, BLA $\rightarrow$ NAc projections regulate both extinction and reinstatement (reprinted from Keistler et al., 2017, Yale University Ph.D. "Elucidating the neural circuitry underlying cuemotivated behavior for food and alcohol"). 
amygdala (BLA) and NAc (Chaudhri et al., 2010; Sinclair et al., 2012; Chaudhri et al., 2013; Millan et al., 2015). It is also known that alcohol-paired cues induce activity in mPFC (Dayas et al., 2007), and alcohol seeking can be perpetuated by alterations in mPFC (Abernathy et al., 2010). While it is thought that the loss of behavioral regulation in addiction results from dysfunction in mesocorticolimbic circuitry (Jentsch and Taylor, 1999), how specific afferents in these pathways control cue-induced alcohol seeking is unknown.

Limitations exist for circuit-based studies that use lesion and inactivation approaches, including those that use contralateral disconnection of specific projections (Setlow et al., 2002). First, disconnections disrupt communication between structures in both directions, making it impossible to dissociate directionality within interconnected circuits. Second, the timing of lesions to target specific behavioral processes that contribute to alcohol seeking can be problematic. These limitations can be addressed by using temporally and directionally controlled neural manipulation techniques, such as viral optogenetic or chemogenetic designer receptor exclusively activated by designer drugs (DREADD) strategies. Despite the specificity of these approaches, there are some issues with regard to studies of drug relapse. Optogenetic stimulation methods are invasive and can be stressful to the behaving animal. This is problematic when studying relapse to alcohol seeking, which is susceptible to stress effects (Lê and Shaham, 2002; Mantsch et al., 2016). Regarding DREADDs, precisely titrating the $\mathrm{CNO}$ (clozapine $\mathrm{N}$-oxide) dose necessary to affect behavior can be a challenge (MacLaren et al., 2016), and compensatory receptor upregulation after chronic inhibitory DREADD stimulation is also a possibility.

Based on the above considerations, we recently developed a novel viral approach to selectively ablate subpopulations of neurons defined by their projection target (Fig. $4 A-F$ ). To accomplish this, we combined a retrogradely transported Cre virus (AAV6-Cre) with a floxed diphtheria toxin (DT) receptor (DTR)-encoding virus (AAVrh10-DIO-DTR-FLAG; Xu et al., 2016; Fig. 4A). By infusing floxed DTR into $\mathrm{mPFC}$ and retrograde Cre virus into either NAc or BLA, DTRs are selectively expressed in mPFC neurons projecting to either of these subcortical structures. Since rodents do not endogenously express DTRs (Middlebrook and Dorland, 1977), only the targeted pathway is subject to ablation via systemic injection of DT. Other studies have accomplished directionally specific chemogenetic inhibition using floxed DREADDs instead of floxed DTR (Carter et al., 2013; Marchant et al., 2016), but our method allows for permanent ablation to be achieved before behavioral assessments to reduce stress of acute systemic injections. Immunohistochemical staining with a FLAG-directed antibody allows the labeling of the targeted circuits to confirm that they had been ablated after systemic DT injections (Fig. $4 B, C$ ), and Cre-directed antibody shows local expression of AAV-Cre in NAc (Fig. 4D). Staining with a cleaved caspase-3 antibody demonstrates apoptosis (Fig. $4 E, F$ ), further validating the specificity of our projection- and direction-specific ablation approach (Keistler et al., 2017).

We used this projection-specific ablation method to examine how limbic corticostriatal projections regulate extinction and cue-induced reinstatement of alcohol seeking. Specific targeted pathways were $\mathrm{mPFC} \rightarrow \mathrm{NAc}, \mathrm{mPFC} \rightarrow \mathrm{BLA}, \mathrm{BLA} \rightarrow \mathrm{NAc}$, and $\mathrm{BLA} \rightarrow$ mPFC. After targeted viral infusions (AAVrh10-DIODTR and AAV6-Cre), we trained rats to self-administer oral alcohol. Next, we ablated the projections by DT injections and then tested the effect of the projection-specific ablations on both extinction and cue-induced reinstatement of alcohol seeking (Fig.
$4 G-I)$. We found that ablating $\mathrm{mPFC} \rightarrow$ NAc blocks cue-induced reinstatement (Fig. 4I) without altering extinction responding (Fig. $4 H$ ), whereas ablating $\mathrm{mPFC} \rightarrow$ BLA had no effects (data not shown). Additionally, ablating the BLA $\rightarrow$ NAc pathway inhibits both extinction and cue-induced reinstatement (summarized in Fig. 4J). Our new unpublished data to be presented in the SFN symposium show that ablation of the BLA $\rightarrow$ mPFC pathway increases the breakpoint for alcohol self-administration on a progressive ratio reinforcement schedule, indicating that the normal function of this projection is to constrain alcohol seeking.

Together, our data provide insight into the role of specific circuits in the regulation of alcohol seeking and complement studies showing that the mPFC and NAc are activated by exposure to alcohol-paired cues after extinction (Dayas et al., 2007), that inactivating NAc decreases cue-induced alcohol seeking (Chaudhri et al., 2010; Millan et al., 2015), and that inactivating $\mathrm{mPFC}$ does not disrupt the expression of extinction (Willcocks and McNally, 2013). Our data also align with a recent study by Kerstetter et al. (2016), who used an analogous DREADDs-based technique to show that inhibiting the $\mathrm{mPFC} \rightarrow$ NAc pathway decreases cocaine priming-induced reinstatement of drug seeking. Given our finding that the $\mathrm{mPFC} \rightarrow$ NAc pathway, a predominantly glutamatergic projection, is necessary for cue-induced reinstatement and the evidence that striatal glutamate levels are increased in recently detoxified alcoholics (Bauer et al., 2013), our results suggest that input from $\mathrm{mPFC}$ provides a hyperglutamatergic tone in NAc, which could contribute to increased alcohol cue sensitivity. Thus, therapies that dampen the activity of $\mathrm{mPFC} \rightarrow$ NAc neurons may be effective in preventing relapse by reducing the motivational effects of alcohol-paired cues.

In conclusion, our novel combinatorial viral approach allows for directional selectivity: DTR expression is Cre dependent and restricted to cells projecting from the AAVrh10-DIO-DTRFLAG infection region to the AAV6-Cre infection region. Importantly, our method also has temporal control, since DT can be injected systemically and noninvasively at any behavioral time point to achieve permanent pathway ablation. This technique for ablating pathways in a target-specific manner with temporal specificity could be used to delineate neural circuits hypothesized to underlie behavior in other animal models of addiction, such as incubation of craving, escalation, and choice-based abstinence models, as well as other psychiatric disorders.

\section{References}

Abernathy K, Chandler LJ, Woodward JJ (2010) Alcohol and the prefrontal cortex. Int Rev Neurobiol 91:289-320. CrossRef Medline

Aghajanian GK (1978) Tolerance of locus coeruleus neurons to morphine and suppression of withdrawal response by clonidine. Nature 276:186188. CrossRef Medline

Ahmed SH (2010) Validation crisis in animal models of drug addiction: beyond non-disordered drug use toward drug addiction. Neurosci Biobehav Rev 35:172-184. CrossRef Medline

Ahmed SH, Koob GF (1998) Transition from moderate to excessive drug intake: change in hedonic set point. Science 282:298-300. CrossRef Medline

Autry AE, Adachi M, Nosyreva E, Na ES, Los MF, Cheng PF, Kavalali ET, Monteggia LM (2011) NMDA receptor blockade at rest triggers rapid behavioural antidepressant responses. Nature 475:91-95. CrossRef Medline

Bauer J, Pedersen A, Scherbaum N, Bening J, Patschke J, Kugel H, Heindel W, Arolt V, Ohrmann P (2013) Craving in alcohol-dependent patients after detoxification is related to glutamatergic dysfunction in the nucleus accumbens and the anterior cingulate cortex. Neuropsychopharmacology 38:1401-1408. CrossRef Medline

Bedi G, Preston KL, Epstein DH, Heishman SJ, Marrone GF, Shaham Y, de Wit H (2011) Incubation of cue-induced cigarette craving during abstinence in human smokers. Biol Psychiatry 69:708-711. CrossRef Medline Bossert JM, Stern AL, Theberge FR, Cifani C, Koya E, Hope BT, Shaham Y 
(2011) Ventral medial prefrontal cortex neuronal ensembles mediate context-induced relapse to heroin. Nat Neurosci 14:420-422. CrossRef Medline

Bossert JM, Marchant NJ, Calu DJ, Shaham Y (2013) The reinstatement model of drug relapse: recent neurobiological findings, emerging research topics, and translational research. Psychopharmacology (Berl) 229:453476. CrossRef Medline

Caprioli D, Venniro M, Zeric T, Li X, Adhikary S, Madangopal R, Marchant NJ, Lucantonio F, Schoenbaum G, Bossert JM, Shaham Y (2015) Effect of the novel positive allosteric modulator of metabotropic glutamate receptor 2 AZD8529 on incubation of methamphetamine craving after prolonged voluntary abstinence in a rat model. Biol Psychiatry 78:463-473. CrossRef Medline

Caprioli D, Venniro M, Zhang M, Bossert JM, Warren BL, Hope BT, Shaham Y (2017) Role of dorsomedial striatum neuronal ensembles in incubation of methamphetamine craving after voluntary abstinence. J Neurosci 37:1014-1027. CrossRef Medline

Carter ME, Soden ME, Zweifel LS, Palmiter RD (2013) Genetic identification of a neural circuit that suppresses appetite. Nature 503:111-114. CrossRef Medline

Chaudhri N, Sahuque LL, Schairer WW, Janak PH (2010) Separable roles of the nucleus accumbens core and shell in context- and cue-induced alcoholseeking. Neuropsychopharmacology 35:783-791. CrossRef Medline

Chaudhri N, Woods CA, Sahuque LL, Gill TM, Janak PH (2013) Unilateral inactivation of the basolateral amygdala attenuates context-induced renewal of Pavlovian-conditioned alcohol-seeking. Eur J Neurosci 38:27512761. CrossRef Medline

Christian DT, Tseng KY, Wolf ME (2017) Extended access cocaine selfadministration leads to increased GluN3-containing NMDA receptor function in the rat nucleus accumbens. Soc Neurosci Abstr 43, 334.15.

Ciccocioppo R, Angeletti S, Weiss F (2001) Long-lasting resistance to extinction of response reinstatement induced by ethanol-related stimuli: role of genetic ethanol preference. Alcohol Clin Exp Res 25:1414-1419. CrossRef Medline

Conrad KL, Tseng KY, Uejima JL, Reimers JM, Heng LJ, Shaham Y, Marinelli M, Wolf ME (2008) Formation of accumbens GluR2-lacking AMPA receptors mediates incubation of cocaine craving. Nature 454:118-121. CrossRef Medline

Creed M, Kaufling J, Fois GR, Jalabert M, Yuan T, Lüscher C, Georges F, Bellone C (2016) Cocaine exposure enhances the activity of ventral tegmental area dopamine neurons via calcium-impermeable NMDARs. J Neurosci 36:10759-10768. CrossRef Medline

Crombag HS, Shaham Y (2002) Renewal of drug seeking by contextual cues after prolonged extinction in rats. Behav Neurosci 116:169-173. CrossRef Medline

Cruz FC, Koya E, Guez-Barber DH, Bossert JM, Lupica CR, Shaham Y, Hope BT (2013) New technologies for examining the role of neuronal ensembles in drug addiction and fear. Nat Rev Neurosci 14:743-754. CrossRef Medline

Cruz FC, Babin KR, Leao RM, Goldart EM, Bossert JM, Shaham Y, Hope BT (2014) Role of nucleus accumbens shell neuronal ensembles in contextinduced reinstatement of cocaine-seeking. J Neurosci 34:7437-7446. CrossRef Medline

Cull-Candy SG, Leszkiewicz DN (2004) Role of distinct NMDA receptor subtypes at central synapses. Sci STKE 2004:re16. CrossRef Medline

Davis GW (2013) Homeostatic signaling and the stabilization of neural function. Neuron 80:718-728. CrossRef Medline

Davis WM, Smith SG (1976) Role of conditioned reinforcers in the initiation, maintenance and extinction of drug-seeking behavior. Pavlov J Biol Sci 11:222-236. Medline

Dayas CV, Liu X, Simms JA, Weiss F (2007) Distinct patterns of neural activation associated with ethanol seeking: effects of naltrexone. Biol Psychiatry 61:979-989. CrossRef Medline

Deroche-Gamonet V, Belin D, Piazza PV (2004) Evidence for addiction-like behavior in the rat. Science 305:1014-1017. CrossRef Medline

de Wit H, Stewart J (1981) Reinstatement of cocaine-reinforced responding in the rat. Psychopharmacology (Berl) 75:134-143. CrossRef Medline

Dong Y, Nestler EJ (2014) The neural rejuvenation hypothesis of cocaine addiction. Trends Pharmacol Sci 35:374-383. CrossRef Medline

Engeln M, Bastide MF, Toulmé E, Dehay B, Bourdenx M, Doudnikoff E, Li Q, Gross CE, Boué-Grabot E, Pisani A, Bezard E, Fernagut PO (2016) Selective inactivation of striatal FosB/DeltaFosB-expressing neurons allevi- ates L-DOPA-induced dyskinesia. Biol Psychiatry 79:354-361. CrossRef Medline

Epstein DH, Preston KL (2003) The reinstatement model and relapse prevention: a clinical perspective. Psychopharmacology 168:31-41. CrossRef Medline

Fanous S, Goldart EM, Theberge FR, Bossert JM, Shaham Y, Hope BT (2012) Role of orbitofrontal cortex neuronal ensembles in the expression of incubation of heroin craving. J Neurosci 32:11600-11609. CrossRef Medline

Ferrario CR, Loweth JA, Milovanovic M, Ford KA, Galiñanes GL, Heng LJ, Tseng KY, Wolf ME (2011) Alterations in AMPA receptor subunits and TARPs in the rat nucleus accumbens related to the formation of $\mathrm{Ca}(2)(+)$-permeable AMPA receptors during the incubation of cocaine craving. Neuropharmacology 61:1141-1151. CrossRef Medline

Field M, Duka T (2002) Cues paired with a low dose of alcohol acquire conditioned incentive properties in social drinkers. Psychopharmacology (Berl) 159:325-334. CrossRef Medline

Funk D, Coen K, Tamadon S, Hope BT, Shaham Y, Lê AD (2016) Role of central amygdala neuronal ensembles in incubation of nicotine craving. J Neurosci 36:8612-8623. CrossRef Medline

Grimm JW, Hope BT, Wise RA, Shaham Y (2001) Neuroadaptation. Incubation of cocaine craving after withdrawal. Nature 412:141-142. CrossRef Medline

Guillem K, Ahmed SH, Peoples LL (2014) Escalation of cocaine intake and incubation of cocaine seeking are correlated with dissociable neuronal processes in different accumbens subregions. Biol Psychiatry 76:31-39. CrossRef Medline

Heinz A, Beck A, Grüsser SM, Grace AA, Wrase J (2009) Identifying the neural circuitry of alcohol craving and relapse vulnerability. Addict Biol 14:108-118. CrossRef Medline

Henson MA, Roberts AC, Pérez-Otaño I, Philpot BD (2010) Influence of the NR3A subunit on NMDA receptor functions. Prog Neurobiol 91:2337. CrossRef Medline

Highfield DA, Mead AN, Grimm JW, Rocha BA, Shaham Y (2002) Reinstatement of cocaine seeking in mice: effects of cocaine priming, cocaine cues and food deprivation. Psychopharmacology 161:417-424. CrossRef Medline

Hollander JA, Carelli RM (2005) Abstinence from cocaine self-administration heightens neural encoding of goal-directed behaviors in the accumbens. Neuropsychopharmacology 30:1464-1474. CrossRef Medline

Hollander JA, Carelli RM (2007) Cocaine-associated stimuli increase cocaine seeking and activate accumbens core neurons after abstinence. J Neurosci 27:3535-3539. CrossRef Medline

Huang YH, Schlüter OM, Dong Y (2011) Cocaine-induced homeostatic regulation and dysregulation of nucleus accumbens neurons. Behav Brain Res 216:9-18. CrossRef Medline

Hunt WA, Barnett LW, Branch LG (1971) Relapse rates in addiction programs. J Clin Psychol 27:455-456. CrossRef Medline

Hyman SE, Malenka RC, Nestler EJ (2006) Neural mechanisms of addiction: the role of reward-related learning and memory. Annu Rev Neurosci 29:565-598. CrossRef Medline

Ishikawa M, Mu P, Moyer JT, Wolf JA, Quock RM, Davies NM, Hu XT, Schlüter OM, Dong Y (2009) Homeostatic synapse-driven membrane plasticity in nucleus accumbens neurons. J Neurosci 29:5820-5831. CrossRef Medline

Jaffe JH, Cascella NG, Kumor KM, Sherer MA (1989) Cocaine-induced cocaine craving. Psychopharmacology 97:59-64. CrossRef Medline

Jentsch JD, Taylor JR (1999) Impulsivity resulting from frontostriatal dysfunction in drug abuse: implications for the control of behavior by reward-related stimuli. Psychopharmacology (Berl) 146:373-390. CrossRef Medline

Jonkman S, Kenny PJ (2013) Molecular, cellular, and structural mechanisms of cocaine addiction: a key role for microRNAs. Neuropsychopharmacology 38:198-211. CrossRef Medline

Kalivas PW (2005) How do we determine which drug-induced neuroplastic changes are important? Nat Neurosci 8:1440-1441. CrossRef Medline

Kalivas PW, O’Brien C (2008) Drug addiction as a pathology of staged neuroplasticity. Neuropsychopharmacology 33:166-180. CrossRef Medline

Kalivas PW, Lalumiere RT, Knackstedt L, Shen H (2009) Glutamate transmission in addiction. Neuropharmacology 56 [Suppl 1]:169-173. CrossRef Medline

Kasof GM, Mandelzys A, Maika SD, Hammer RE, Curran T, Morgan JI (1995) Kainic acid-induced neuronal death is associated with DNA dam- 
age and a unique immediate-early gene response in c-fos-lac $Z$ transgenic rats. J Neurosci 15:4238-4249. Medline

Katner SN, Weiss F (1999) Ethanol-associated olfactory stimuli reinstate ethanol-seeking behavior after extinction and modify extracellular dopamine levels in the nucleus accumbens. Alcohol Clin Exp Res 23:17511760. CrossRef Medline

Kavalali ET, Monteggia LM (2015) How does ketamine elicit a rapid antidepressant response? Curr Opin Pharmacol 20:35-39. CrossRef Medline

Keistler CR, Hammarlund E, Barker JM, Bond CW, DiLeone RJ, Pittenger C, Taylor JR (2017) Regulation of alcohol extinction and cue-induced reinstatement by specific projections among medial prefrontal cortex, nucleus accumbens, and basolateral amygdala. J Neurosci 37:4462-4471. CrossRef Medline

Kerstetter KA, Wunsch AM, Nakata KG, Donckels E, Neumaier JF, Ferguson SM (2016) Corticostriatal afferents modulate responsiveness to psychostimulant drugs and drug-associated stimuli. Neuropsychopharmacology 41:1128-1137. CrossRef Medline

Koob GF, Le Moal M (1997) Drug abuse: hedonic homeostatic dysregulation. Science 278:52-58. CrossRef Medline

Kowalczyk WJ, Phillips KA, Jobes ML, Kennedy AP, Ghitza UE, Agage DA, Schmittner JP, Epstein DH, Preston KL (2015) Clonidine maintenance prolongs opioid abstinence and decouples stress from craving in daily life: a randomized controlled trial with ecological momentary assessment. Am J Psychiatry 172:760-767. CrossRef Medline

Koya E, Golden SA, Harvey BK, Guez-Barber DH, Berkow A, Simmons DE, Bossert JM, Nair SG, Uejima JL, Marin MT, Mitchell TB, Farquhar D, Ghosh SC, Mattson BJ, Hope BT (2009) Targeted disruption of cocaineactivated nucleus accumbens neurons prevents context-specific sensitization. Nat Neurosci 12:1069-1073. CrossRef Medline

LaRowe SD, Kalivas PW, Nicholas JS, Randall PK, Mardikian PN, Malcolm RJ (2013) A double-blind placebo-controlled trial of N-acetylcysteine in the treatment of cocaine dependence. Am J Addict 22:443-452. CrossRef Medline

Lê A, Shaham Y (2002) Neurobiology of relapse to alcohol in rats. Pharmacol Ther 94:137-156. CrossRef Medline

Lee BR, Ma YY, Huang YH, Wang X, Otaka M, Ishikawa M, Neumann PA, Graziane NM, Brown TE, Suska A, Guo C, Lobo MK, Sesack SR, Wolf ME, Nestler EJ, Shaham Y, Schlüter OM, Dong Y (2013) Maturation of silent synapses in amygdala-accumbens projection contributes to incubation of cocaine craving. Nat Neurosci 16:1644-1651. CrossRef Medline

Lenoir M, Ahmed SH (2007) Heroin-induced reinstatement is specific to compulsive heroin use and dissociable from heroin reward and sensitization. Neuropsychopharmacology 32:616-624. CrossRef Medline

Li P, Wu P, Xin X, Fan YL, Wang GB, Wang F, Ma MY, Xue MM, Luo YX, Yang FD, Bao YP, Shi J, Sun HQ, Lu L (2015a) Incubation of alcohol craving during abstinence in patients with alcohol dependence. Addict Biol 20:513-522. CrossRef Medline

Li X, Rubio FJ, Zeric T, Bossert JM, Kambhampati S, Cates HM, Kennedy PJ, Liu QR, Cimbro R, Hope BT, Nestler EJ, Shaham Y (2015b) Incubation of methamphetamine craving is associated with selective increases in expression of Bdnf and trkb, glutamate receptors, and epigenetic enzymes in cue-activated fos-expressing dorsal striatal neurons. J Neurosci 35:82328244. CrossRef Medline

Li X, Venniro M, Shaham Y (2016) Translational research on incubation of cocaine craving. JAMA Psychiatry 73:1115-1116. CrossRef Medline

Loweth JA, Tseng KY, Wolf ME (2013) Using metabotropic glutamate receptors to modulate cocaine's synaptic and behavioral effects: mGluR1 finds a niche. Curr Opin Neurobiol 23:500-506. CrossRef Medline

Loweth JA, Scheyer AF, Milovanovic M, LaCrosse AL, Flores-Barrera E, Werner CT, Li X, Ford KA, Le T, Olive MF, Szumlinski KK, Tseng KY, Wolf ME (2014) Synaptic depression via mGluR1 positive allosteric modulation suppresses cue-induced cocaine craving. Nat Neurosci 17:73-80. CrossRef Medline

Lu L, Grimm JW, Hope BT, Shaham Y (2004) Incubation of cocaine craving after withdrawal: a review of preclinical data. Neuropharmacology 47 [Suppl 1]:214-226. CrossRef Medline

Lu L, Hope BT, Dempsey J, Liu SY, Bossert JM, Shaham Y (2005) Central amygdala ERK signaling pathway is critical to incubation of cocaine craving. Nat Neurosci 8:212-219. CrossRef Medline

Lu L, Uejima JL, Gray SM, Bossert JM, Shaham Y (2007) Systemic and central amygdala injections of the mGluR(2/3) agonist LY379268 attenuate the expression of incubation of cocaine craving. Biol Psychiatry 61:591598. CrossRef Medline

Ma YY, Lee BR, Wang X, Guo C, Liu L, Cui R, Lan Y, Balcita-Pedicino JJ, Wolf ME, Sesack SR, Shaham Y, Schlüter OM, Huang YH, Dong Y (2014) Bidirectional modulation of incubation of cocaine craving by silent synapse-based remodeling of prefrontal cortex to accumbens projections. Neuron 83:1453-1467. CrossRef Medline

MacLaren DA, Browne RW, Shaw JK, Krishnan Radhakrishnan S, Khare P, Espana RA, Clark SD (2016) Clozapine N-Oxide administration produces behavioral effects in Long-Evans rats: implications for designing DREADD experiments. eNeuro 3:1-14. CrossRef Medline

Mantsch JR, Baker DA, Funk D, Lê AD, Shaham Y (2016) Stress-induced reinstatement of drug seeking: 20 years of progress. Neuropsychopharmacology 41:335-356. CrossRef Medline

Marchant NJ, Li X, Shaham Y (2013) Recent developments in animal models of drug relapse. Curr Opin Neurobiol 23:675-683. CrossRef Medline

Marchant NJ, Campbell EJ, Harvey BK, Kaganovsky K, Adhikary S, Heins R, Whitaker LR, Hope BT, Prisinzano TE, Vardy E, Bonci A, Bossert JM, Shaham Y (2016) Role of ventral subiculum in context-induced relapse to alcohol seeking after punishment-imposed abstinence. J Neurosci 36: 3281-3294. CrossRef Medline

Marlatt AG (1996) Models of relapse and relapse prevention: a commentary. Exp Clin Psychopharmacol 4:55-60. CrossRef

McCutcheon JE, Wang X, Tseng KY, Wolf ME, Marinelli M (2011a) Calcium-permeable AMPA receptors are present in nucleus accumbens synapses after prolonged withdrawal from cocaine self-administration but not experimenter-administered cocaine. J Neurosci 31:5737-5743. CrossRef Medline

McCutcheon JE, Loweth JA, Ford KA, Marinelli M, Wolf ME, Tseng KY (2011b) Group I mGluR activation reverses cocaine-induced accumulation of calcium-permeable AMPA receptors in nucleus accumbens synapses via a protein kinase C-dependent mechanism. J Neurosci 31: 14536-14541. CrossRef Medline

Meil WM, See RE (1996) Conditioned cued recovery of responding following prolonged withdrawal from self-administered cocaine in rats: an animal model of relapse. Behav Pharmacol 7:754-763. Medline

Middlebrook JL, Dorland RB (1977) Response of cultured mammalian cells to the exotoxins of Pseudomonas aeruginosa and Corynebacterium diphtheriae: differential cytotoxicity. Can J Microbiol 23:183-189. CrossRef Medline

Millan EZ, Reese RM, Grossman CD, Chaudhri N, Janak PH (2015) Nucleus accumbens and posterior amygdala mediate cue-triggered alcohol seeking and suppress behavior during the omission of alcohol-predictive cues. Neuropsychopharmacology 40:2555-2565. CrossRef Medline

Morgan JI, Curran T (1991) Stimulus-transcription coupling in the nervous system: involvement of the inducible proto-oncogenes fos and jun. Annu Rev Neurosci 14:421-451. CrossRef Medline

Nestler EJ (2001) Molecular basis of long-term plasticity underlying addiction. Nat Rev Neurosci 2:119-128. CrossRef Medline

Nestler EJ, Aghajanian GK (1997) Molecular and cellular basis of addiction. Science 278:58-63. CrossRef Medline

O’Brien CP (2005) Anticraving medications for relapse prevention: a possible new class of psychoactive medications. Am J Psychiatry 162:14231431. CrossRef Medline

O’Brien CP, Ehrman RN, Ternes JW (1986) Classical conditioning in human opioid dependence. In: Behavioral analysis of drug dependence (Goldberg S, Stolerman I, eds), pp 329-356. Orlando, FL: Academic.

O’Donnell P, Greene J, Pabello N, Lewis BL, Grace AA (1999) Modulation of cell firing in the nucleus accumbens. Ann N Y Acad Sci 877:157-175. CrossRef Medline

Pachernegg S, Strutz-Seebohm N, Hollmann M (2012) GluN3 subunitcontaining NMDA receptors: not just one-trick ponies. Trends Neurosci 35:240-249. CrossRef Medline

Paoletti P, Bellone C, Zhou Q (2013) NMDA receptor subunit diversity: impact on receptor properties, synaptic plasticity and disease. Nat Rev Neurosci 14:383-400. CrossRef Medline

Parvaz MA, Moeller SJ, Goldstein RZ (2016) Incubation of cue-induced craving in adults addicted to cocaine measured by electroencephalography. JAMA Psychiatry 73:1127-1134. CrossRef Medline

Pfarr S, Meinhardt MW, Klee ML, Hansson AC, Vengeliene V, Schönig K, Bartsch D, Hope BT, Spanagel R, Sommer WH (2015) Losing control: excessive alcohol seeking after selective inactivation of cue-responsive 
neurons in the infralimbic cortex. J Neurosci 35:10750-10761. CrossRef Medline

Pickens CL, Airavaara M, Theberge F, Fanous S, Hope BT, Shaham Y (2011) Neurobiology of the incubation of drug craving. Trends Neurosci 34:411420. CrossRef Medline

Purgianto A, Scheyer AF, Loweth JA, Ford KA, Tseng KY, Wolf ME (2013) Different adaptations in AMPA receptor transmission in the nucleus accumbens after short vs long access cocaine self-administration regimens. Neuropsychopharmacology 38:1789-1797. CrossRef Medline

Reese AL, Kavalali ET (2015) Spontaneous neurotransmission signals through store-driven $\mathrm{Ca}(2+)$ transients to maintain synaptic homeostasis. Elife 4:e09262. CrossRef Medline

Rubio FJ, Liu QR, Li X, Cruz FC, Leão RM, Warren BL, Kambhampati S, Babin KR, McPherson KB, Cimbro R, Bossert JM, Shaham Y, Hope BT (2015) Context-induced reinstatement of methamphetamine seeking is associated with unique molecular alterations in Fos-expressing dorsolateral striatum neurons. J Neurosci 35:5625-5639. CrossRef Medline

Scheetz AJ, Nairn AC, Constantine-Paton M (2000) NMDA receptormediated control of protein synthesis at developing synapses. Nat Neurosci 3:211-216. CrossRef Medline

Scheyer AF, Wolf ME, Tseng KY (2014) A protein synthesis-dependent mechanism sustains calcium-permeable AMPA receptor transmission in nucleus accumbens synapses during withdrawal from cocaine selfadministration. J Neurosci 34:3095-3100. CrossRef Medline

Schwandt ML, Cortes CR, Kwako LE, George DT, Momenan R, Sinha R, Grigoriadis DE, Pich EM, Leggio L, Heilig M (2016) The CRF1 antagonist verucerfont in anxious alcohol-dependent women: translation of neuroendocrine, but not of anti-craving effects. Neuropsychopharmacology 41:2818-2829. CrossRef Medline

Self DW (2004) Regulation of drug-taking and -seeking behaviors by neuroadaptations in the mesolimbic dopamine system. Neuropharmacology 47 [Suppl 1]:242-255. CrossRef Medline

Setlow B, Holland PC, Gallagher M (2002) Disconnection of the basolateral amygdala complex and nucleus accumbens impairs appetitive pavlovian second-order conditioned responses. Behav Neurosci 116:267-275. CrossRef Medline

Shaham Y, Hope BT (2005) The role of neuroadaptations in relapse to drug seeking. Nat Neurosci 8:1437-1439. CrossRef Medline

Shaham Y, Stewart J (1995) Stress reinstates heroin self-administration behavior in drug-free animals: an effect mimicking heroin, not withdrawal. Psychopharmacology 119:334-341. CrossRef Medline

Shaham Y, Rajabi H, Stewart J (1996) Relapse to heroin-seeking in rats under opioid maintenance: the effects of stress, heroin priming, and withdrawal. J Neurosci 16:1957-1963. Medline

Shaham Y, Shalev U, Lu L, De Wit H, Stewart J (2003) The reinstatement model of drug relapse: history, methodology and major findings. Psychopharmacology 168:3-20. CrossRef Medline

Sinclair CM, Cleva RM, Hood LE, Olive MF, Gass JT (2012) mGluR5 receptors in the basolateral amygdala and nucleus accumbens regulate cueinduced reinstatement of ethanol-seeking behavior. Pharmacol Biochem Behav 101:329-335. CrossRef Medline

Sinha R (2001) How does stress increase risk of drug abuse and relapse. Psychopharmacology 158:343-359. CrossRef Medline

Sinha R (2011) New findings on biological factors predicting addiction relapse vulnerability. Curr Psychiatry Rep 13:398-405. CrossRef Medline

Sinha R, Li CS (2007) Imaging stress- and cue-induced drug and alcohol craving: association with relapse and clinical implications. Drug Alcohol Rev 26:25-31. CrossRef Medline

Sinha R, Shaham Y, Heilig M (2011) Translational and reverse translational research on the role of stress in drug craving and relapse. Psychopharmacology (Berl) 218:69-82. CrossRef Medline

Solomon RL, Corbit JD (1974) An opponent process theory of motivation. I. Temporal dynamics of affect. Psychol Rev 81:119-145. CrossRef Medline

Stewart J, de Wit H (1987) Reinstatement of drug-taking behavior as a method of assessing incentive motivational properties of drugs. In: Meth- ods of assessing the reinforcing properties of abused drugs (Bozarth MA, ed), pp 211-227. New York: Springer.

Stretch R, Gerber GJ, Wood SM (1971) Factors affecting behavior maintained by response-contingent intravenous infusions of amphetamine in squirrel monkeys. Can J Physiol Pharmacol 49:581-589. CrossRef Medline

Sutton MA, Ito HT, Cressy P, Kempf C, Woo JC, Schuman EM (2006) Miniature neurotransmission stabilizes synaptic function via tonic suppression of local dendritic protein synthesis. Cell 125:785-799. CrossRef Medline

Thomas MJ, Kalivas PW, Shaham Y (2008) Neuroplasticity in the mesolimbic dopamine system and cocaine addiction. Br J Pharmacol 154:327-342. CrossRef Medline

Turrigiano GG, Nelson SB (2004) Homeostatic plasticity in the developing nervous system. Nat Rev Neurosci 5:97-107. CrossRef Medline

Valjent E, Corvol JC, Pages C, Besson MJ, Maldonado R, Caboche J (2000) Involvement of the extracellular signal-regulated kinase cascade for cocaine-rewarding properties. J Neurosci 20:8701-8709. Medline

Venniro M, Caprioli D, Shaham Y (2016) Animal models of drug relapse and craving: from drug priming-induced reinstatement to incubation of craving after voluntary abstinence. Prog Brain Res 224:25-52. CrossRef Medline

Venniro M, Zhang M, Shaham Y, Caprioli D (2017a) Incubation of methamphetamine but not heroin craving after voluntary abstinence in male and female rats. Neuropsychopharmacolgy 42:1126-1135.

Venniro M, Caprioli D, Zhang M, Whitaker LR, Zhang S, Wang HL, Warren BL, Cifani C, Marchant NJ, Yizhar O, Harvey BL, Bossert JM, Chiamulera C, Morales M, Shaham Y (2017b) The anterior insular cortex $\rightarrow$ central amygdala glutamatergic pathway is critical to relapse after contingency management. Neuron, in press.

Wang F, Flanagan J, Su N, Wang LC, Bui S, Nielson A, Wu X, Vo HT, Ma XJ, Luo Y (2012) RNAscope: a novel in situ RNA analysis platform for formalin-fixed, paraffin-embedded tissues. J Mol Diagn 14:22-29. CrossRef Medline

Wang G, Shi J, Chen N, Xu L, Li J, Li P, Sun Y, Lu L (2013) Effects of length of abstinence on decision-making and craving in methamphetamine abusers. PLoS One 8:e68791. CrossRef Medline

Weiss F (2005) Neurobiology of craving, conditioned reward and relapse. Curr Opin Pharmacol 5:9-19. CrossRef Medline

White NM (1996) Addictive drugs as reinforcers: multiple partial actions on memory systems. Addiction 91:921-949. CrossRef Medline

Wikler A (1973) Dynamics of drug dependence. Implications of a conditioning theory for research and treatment. Arch Gen Psychiatry 28:611616. CrossRef Medline

Willcocks AL, McNally GP (2013) The role of medial prefrontal cortex in extinction and reinstatement of alcohol-seeking in rats. Eur J Neurosci 37:259-268. CrossRef Medline

Wolf ME (2016) Synaptic mechanisms underlying persistent cocaine craving. Nat Rev Neurosci 17:351-365. CrossRef Medline

Wolf ME, Tseng KY (2012) Calcium-permeable AMPA receptors in the VTA and nucleus accumbens after cocaine exposure: when, how, and why? Front Mol Neurosci 5:72. CrossRef Medline

Xu M, Li L, Pittenger C (2016) Ablation of fast-spiking interneurons in the dorsal striatum, recapitulating abnormalities seen post-mortem in Tourette syndrome, produces anxiety and elevated grooming. Neuroscience 324:321-329. CrossRef Medline

Xue YX, Chen YY, Zhang LB, Zhang LQ, Huang GD, Sun SC, Deng JH, Luo YX, Bao YP, Wu P, Hope BT, Shaham Y, Shi J, Lu L (2017) Selective inhibition of amygdala neuronal ensembles encoding nicotine-associated memories prevents nicotine craving and relapse. Biol Psychiatry, in press.

Yee AX, Hsu YT, Chen L (2017) A metaplasticity view of the interaction between homeostatic and Hebbian plasticity. Philos Trans R Soc Lond B Biol Sci 372:20160155. CrossRef Medline

Yuan T, Mameli M, O'Connor EC, Dey PN, Verpelli C, Sala C, Perez-Otano I, Lüscher C, Bellone C (2013) Expression of cocaine-evoked synaptic plasticity by GluN3A-containing NMDA receptors. Neuron 80:10251038. CrossRef Medline 